\title{
Introduction: Argument Studies in Poland
}

\author{
Katarzyna Budzynska • Marcin Koszowy
}

Published online: 8 June 2014

(C) The Author(s) 2014. This article is published with open access at Springerlink.com

Contemporary argument studies in Poland began with the research of the LvovWarsaw School and its successors in Artificial Intelligence and legal theory, as well as with the studies of Polish rhetoricians (Koszowy and Araszkiewicz 2014; Budzynska et al. 2014) (see also van Eemeren et al. 2015; Koszowy 2011; Załęska 2012). The last decade has witnessed a major transformation in the Polish landscape, beginning with several landmark publications (see e.g. Dignum et al. 2001; Grabowski 2003; Lichański 2003; Smolak 2003; Szymanek et al. 2003; Bogołębska 2006; Tokarz 2006; Hołówka 2007; Dunin-Kęplicz and Verbrugge 2010; Gizbert-Studnicki 2012) which have attracted an ever-growing number of young researchers and students. As a result, the research movement of the Polish School of Argumentation has begun to emerge (see Sect. 1).

In 2008, the nationwide initiative ArgDiaP (http://argdiap.pl/) was established in order to provide infrastructure facilitating the networking process and to foster research on argumentation in Poland, including the research of the Polish School of Argumentation (see Sect. 2). In 2013, the 11th ArgDiaP workshop hosted an interdisciplinary group of Polish scholars, who discussed the present state of the art and future directions of argument studies in Poland. This discussion resulted in a Manifesto co-authored by 55 representatives of the School and published as the opening article (Budzynska et al. 2014) of this special issue.

\footnotetext{
K. Budzynska ( $\bowtie)$

Institute of Philosophy and Sociology, Polish Academy of Sciences, Warsaw, Poland e-mail: budzynska.argdiap@gmail.com

M. Koszowy

Department of Logic, Informatics and Philosophy of Science, University of Białystok, Białystok,

Poland

e-mail: koszowy@uwb.edu.pl
} 
The collection of papers presented in the issue 'The Polish School of Argumentation' explores the scope and dynamics of argumentation research in Poland (see Sect. 3). As its guest editors, we aimed to continue an inspiring dialogue in which Polish scholars engage with the broader international community during ArgDiaP workshops. Therefore we asked contributors to the Polish School to submit extended versions of papers presented at these workshops, and then invited leading international experts to comment on each paper.

\section{The Polish School of Argumentation}

The Polish School of Argumentation (Budzynska et al. 2014) is a research movement that integrates different disciplines and institutions across Poland. It brings together people with a common research focus, complementary skills and an enthusiasm to work together. The School's members are interested in understanding the phenomenon of the force of argument, with a particular focus on reason, trust, and cognition.

The diversity of approaches to argumentation in Poland is striking, encompassing logic, philosophy, psychology, law, linguistics, rhetoric, mathematics, computer science, sociology and education ( $c f$. Fig. 1). ${ }^{1}$ Perhaps unsurprisingly, many institutions (seven universities and research institutes) are concentrated in Warsaw. The predominant specialisations include philosophy, logic, mathematics and computer science, although representatives of almost all of the disciplines mentioned above can be found here.

Other important institutions in central Poland are located in Poznań, Łódź and Torun, where many argumentation scholars specialise in linguistics and logic. In the south, three more important centres can be identified: (from east to west) Lublin (with an emphasis on philosophy), Krakow \& Katowice (placing equal emphasis on law, logic and philosophy), and Wrocław \& Opole (concentrating on logic). Finally, northern Poland has two key centres-Białystok (with a focus on logic and computer science) and Szczecin (focusing on philosophy and linguistics).

In 2013, the Polish School of Argumentation established its foundations and research programme. In Oct 2013 we organised the 11th ArgDiaP workshop in Warsaw, dedicated entirely to discussing the present state of the art and future directions of argument studies in Poland. Before the meeting, a group of ten researchers-Araszkiewicz (law, Krakow), Budzynska (philosophy, Warsaw), Debowska-Kozlowska (linguistics, Poznań), Kacprzak (computer science, Białystok), Koszowy (philosophy, Białystok), Selinger (logic, Wrocław), Szymanek (logic, Katowice), Urbański (cognitive science, Poznań), Yaskorska (logic, Warsaw), and Witek (cognitive science, Szczecin)—-met to prepare a draft document that was to serve as a list of topics to trigger a discussion planned for ArgDiaP. ${ }^{2}$

\footnotetext{
${ }^{1}$ Note that the statistics presented in this section are not the result of systematic analysis and their purpose is only to illustrate tendencies in argument studies in Poland. All the data are calculated for the authors of the Manifesto; the actual data may vary.

${ }^{2}$ See (Budzynska et al. 2014) for more detailed information, e.g. the affiliations of the co-authors of the research programme announced in the Manifesto.
} 


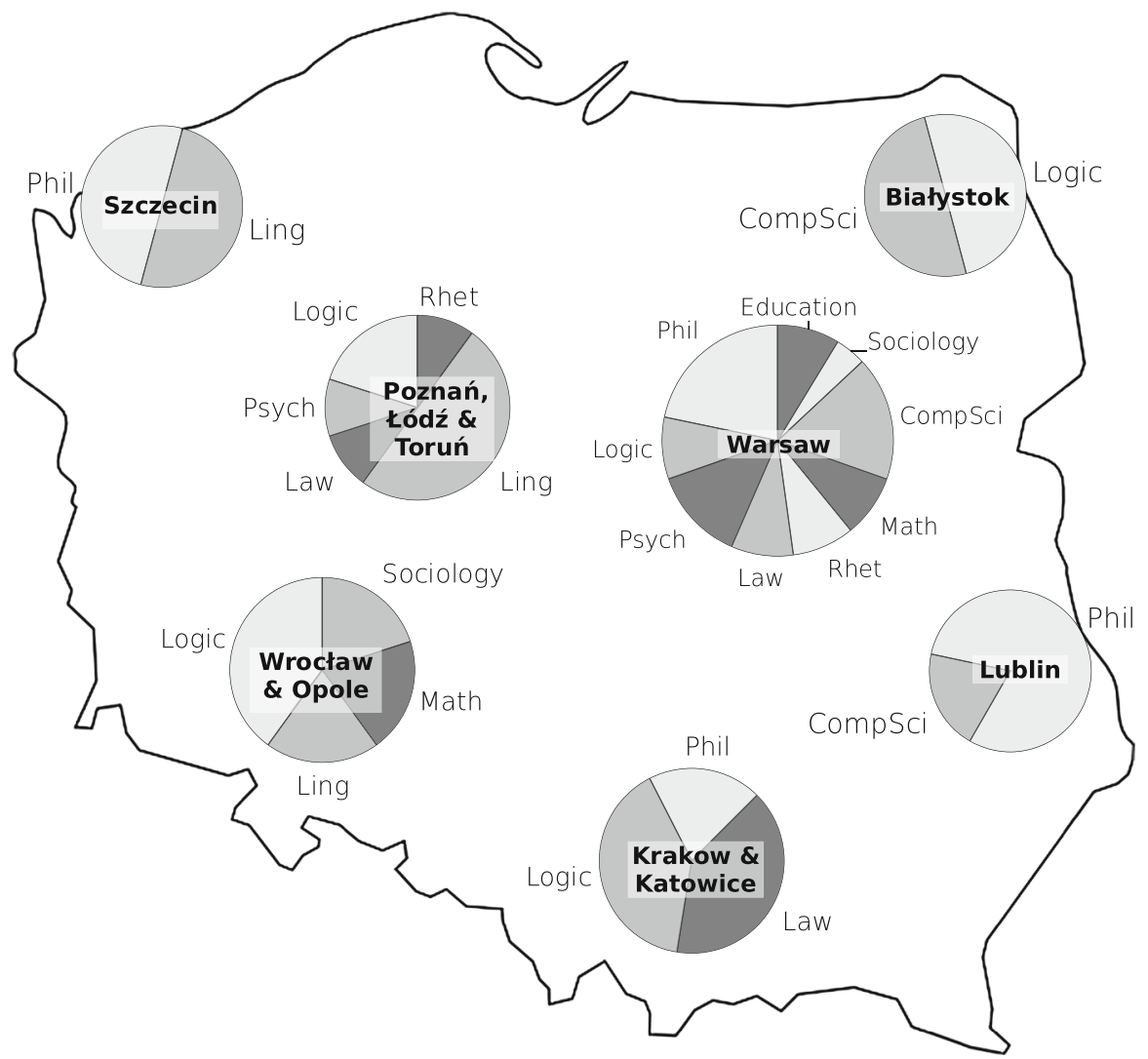

Fig. 1 Concentration of disciplines in major regions of Poland (based on the proportion of Manifesto coauthors in each discipline)

Next, ten outstanding experts representing different areas of the School's specialisation accepted an invitation to ArgDiaP's panel sessions: Bogołębska (rhetoric, Łódź), Federowicz (education, Warsaw), Grabowski (law, Krakow), Kawalec (philosophy, Lublin), Lichański (rhetoric, Warsaw), Marciszewski (logic, Białystok), Smolak (law, Poznań), Stalmaszczyk (linguistics, Łódź), Stawecki (law, Warsaw), and Załęska (rhetoric, Warsaw). The draft document was circulated among them before the ArgDiaP meeting, and their role was to further elaborate on it in order to encourage and support a fruitful and in-depth exchange of ideas.

Another seventeen leading researchers, who could not take part in the 11th ArgDiaP, offered written contributions to the discussion: Cap (linguistics, Łódź), Ciecierski (philosophy, Warsaw), Dunin-Kȩplicz (computer science, Warsaw), Gomolińska (computer science, Białystok), Hołówka (logic, Warsaw), Kisielewicz (mathematics, Wrocław), Kulicki (philosophy, Lublin), Malinowski (logic, Warsaw \& Toruń), Pogonowski (logic, Poznań), Puczyłowski (philosophy, Warsaw), Skowron (mathematics, Warsaw), Stepaniuk (computer science, Białystok), Strachocka (computer science, Warsaw), Suchoń (philosophy, Krakow), Trypuz 
(philosophy, Lublin), Trzȩsicki (logic, Białystok), and Wybraniec-Skardowska (logic, Opole).

Finally, eighteen outstanding position papers which were accepted to be presented as short contributions at the ArgDiaP meeting were authored by Dziubiński (computer science, Warsaw), Jochemczyk (psychology, Warsaw), Kielar (linguistics, Poznań), Kublikowski (philosophy, Lublin), Kuzio (linguistics, Zielona Góra), Lewiński (linguistics, Wrocław), Nieznański (law, Warsaw), Pietrzak (psychology, Warsaw), Rytel (psychology, Warsaw), Sawicka (computer science, Warsaw), Skulska (philosophy, Warsaw), Sokół (linguistics, Szczecin), Sowińska (linguistics, Toruń), Tomczyk (sociology, Wrocław), Wasilewska-Kamińska (education, Warsaw), Wieczorek (logic, Katowice), Zdanowski (mathematics, Warsaw), and Żurek (computer science, Lublin).

The ArgDiaP workshop took place in Warsaw on 25th-26th October 2013 at the Institute of Philosophy and Sociology of the Polish National Academy of Sciences, in the Staszic Palace. All contributions were presented individually and then discussed during two panel sessions at the end of each day of the workshop. The panels focused on specific issues: the discussion on Friday focused on methodological issues for interdisciplinary studies, while the panel on Saturday was more oriented towards problems related to the challenges of infrastructural implementation of the School's programme, including a strategy plan for education.

After the ArgDiaP meeting, the discussion was summarised and reported as a first draft of the paper The Polish School of Argumentation: A Manifesto. The draft was then circulated among all the co-authors (contributors) for consultation in several iterations. The process was concluded with a version that was published as the opening article (Budzynska et al. 2014) of this special issue.

\section{ArgDiaP Initiative}

The origins of the special issue dedicated to the Polish School of Argumentation lie in the ArgDiaP initiative (http://argdiap.pl/) established in 2008. ArgDiaP provides infrastructure for argument studies in Poland supporting a variety of activities, including workshops, graduate schools and publications. Since 2008, we have organised 11 semi-annual one-day meetings at which 60 papers have been presented, hosting over 50 speakers from 20 leading Polish universities and research institutes, and 10 speakers from the US, Canada, Germany, the Netherlands, Sweden and the UK. Our special guests have included Frans van Eemeren (Amsterdam), Leo Groarke (Windsor, Canada), Chris Reed (Dundee, UK) and John R. Searle (Berkeley). The Stanford Encyclopedia of Philosophy recognised the ArgDiaP workshops as one of the world's most important events in the theory of argumentation.

This special issue of Argumentation is a collection of expanded versions of papers delivered by members of the Polish School at the international editions of the ArgDiaP workshops. The links between the research undertaken within the School and the current state of the art in argumentation theory are emphasised by 
commentary papers authored by outstanding representatives of the broader international community of argumentation scholars.

The Interdisciplinary Graduate School on Argumentation and Rhetoric (IGSAR) has been associated with ArgDiaP conferences since 2013. Our long-term mission is to contribute to the establishment of teaching standards by implementing the theoretical development of the School and to support the best educational practices for argumentation theory in Poland.

ArgDiaP also coordinates an argumentation series published in the Polish journal Studies in Logic, Grammar and Rhetoric http://logika.uwb.edu.pl/studies/ (SLGR). The unique profile of SLGR lies in its exploitation of the three classical fields of the medieval trivium in its studies of communication phenomena. Since 2009 three volumes of the argumentation series have been released, dedicated to major research strands in the philosophy of argument (Koszowy 2009), computational approaches to argumentation (Koszowy 2011), and pragmatics and dialectics of argument (Budzynska et al. 2014). The release of the most recent volume coincides with that of this special issue of Argumentation, supporting further interaction between the Polish School and the international community; authors contributing to this volume of SLGR included John R. Searle (Berkeley), Francisca Snoeck Henkemans (Amsterdam), Peter Simons (Dublin), Jim Mackenzie (Sydney), and Jan Albert van Laar (Groningen).

\section{The Special Issue}

This special issue, 'The Polish School of Argumentation', consists of ten papers. The first two papers lay the foundations for the programme of our research movement: its manifesto and applications of the Polish research tradition in argument studies. The next eight papers are dedicated to specific aspects of the force of argument - the main focus of the School's investigations. Each aspect is explored in two papers: one by a representative of the Polish School and a commentary paper by a member of the broader international community.

As guest editors, we aimed not only to show the interaction between researchers working in Polish academia and experts from international centres for argument studies, but also to demonstrate the role of those who share the same academic heritage and are working to fuse it with other scholarly traditions all around the world.

Research programme and foundations consists of two papers- the manifesto by Katarzyna Budzynska et al., and an article further elaborating on the Polish research heritage in argument studies by Marcin Koszowy (philosophy \& logic, Białystok) and Michał Araszkiewicz (law \& computational models of argument, Krakow).

The special issue opens with a paper that lays out the central themes and main approaches of the Polish School of Argumentation. This statement-the Manifesto-is co-authored by 55 contributors to the School, representing a variety of disciplines and 20 Polish institutions. The paper gives an outline of the research programme, which is based on the idea of systematic study of the force of argument with a focus on reason, trust and cognition. The manifesto describes the 
methodological programme for the interdisciplinary approach, the roots and main research topics of the School, and its organisation and infrastructure.

Koszowy and Araszkiewicz further examine the roots of the Polish School of Argumentation. They claim that the heritage of the Lvov-Warsaw School can be a source of inspiration for the study of the formal and pragmatic force of argument. In particular, the paper shows how the ideas of Ajdukiewicz, Bocheński and Frydman may be employed in solving contemporary open problems in argumentation theory, and thus it paves the way to a systematic inquiry into the overlap between the roots of the School and future developments in argument studies.

Pragmatic force of argument: a paper by Katarzyna Budzynska (philosophy \& computational models of argument, Warsaw \& Dundee) and Maciej Witek (philosophy of language \& cognitive science, Szczecin), commented on by Douglas Walton (philosophy \& Artificial Intelligence, Windsor, Canada).

Budzynska and Witek explore the interrelation between persuasion tactics and the properties of speech acts. They investigate the rhetorical and pragmatic facets of two types of ad arguments: ad hominem and ad baculum. In his reply, Walton stresses the specific ways in which Budzynska and Witek's paper constitutes an important contribution to the current state of the art in the study of the nature of ad hominem and ad baculum. In order to show how Budzynska and Witek's speech-act approach to modelling non-inferential aspects of these argumentative techniques may be further applied in research on the topic, Walton argues that yet another factor should be considered in modelling ad baculum arguments, i.e. contextual information about the framework of the dialogue in which this type of argument is embedded.

Persuasive force of argument: a paper by Kamila Debowska-Kozlowska (linguistics, Poznań), commented on by Fabio Paglieri (cognitive science, Rome).

Debowska-Kozlowska focuses on the persuasive force of argument by proposing a Cognitive Beneficial Model of persuasion. This model allows for the formulation of modified versions of a given standpoint which are needed to obtain two additional effects of persuasion: partially-successful dialogues and over-successful dialogues. In his commentary paper, Paglieri points out some directions for the future development of the model proposed by Debowska-Kozlowska. Key questions which may be an interesting starting point for future discussion include the following: What is the most adequate notion of persuasion? Is it sufficient to discuss the outcomes of persuasion exclusively in terms of success and failure? How can we explicate the notion of topic and what is the most accurate understanding of partial and excessive success?

Dialectical force of argument: a paper by Magdalena Kacprzak (computer science \& mathematics, Białystok) and Olena Yaskorska (logic \& linguistics, Warsaw), commented on by Wilfrid Hodges (logic \& mathematics, Okehampton, UK).

Kacprzak and Yaskorska propose a tool for the evaluation of the force of argument in dialogical scenarios in which players advance deductively incorrect arguments. The authors present a formal dialogue system called Lorenzen-Hamblin Natural Dialogue (LHND), in which participants are allowed to commit formal fallacies but have a method of both identifying and withdrawing them. Taking into account the point of view of mathematical logic, Hodges explores the links between 
Kacprzak and Yaskorska's proposal and the most significant dialogue approaches to discussion and reasoning. He analyses in detail Lorenzen and Hamblin's accounts of dialogue and the meaning of key terms such as claiming, conceding and commitment, particularly with respect to claiming and conceding in dialogues.

Logical force of argument: a paper by Marcin Selinger (logic \& philosophy, Wrocław), commented on by Chris Reed (computer science \& philosophy, Dundee, Scotland).

Selinger proposes a formal model of representation and numerical evaluation of a broad class of arguments, including those that occur in natural discourse, with special attention given to calculating the logical force of convergent arguments. Reed comments on this idea by discussing in detail some significant affinities between Selinger's model and the latest computational approaches to structured argumentation and argument aggregation. Despite the fact that Selinger comes from a different research background, associated with the heritage of the Lvov-Warsaw School, his endpoints are strikingly similar to solutions proposed by researchers such as Prakken, and his ambitious treatment of aggregation is in line with recent developments in the domain of AI reasoning systems.

The papers were selected on the basis of reviews by outstanding scholars (see the panel of experts below). We are grateful to them for their hard work and strong support at all stages of the editorial process. We would also like to thank Frans van Eemeren and Bart Garssen for their valuable advice and fruitful collaboration. Finally, we gratefully acknowledge the support of the Polish National Science Centre for Budzynska and Koszowy under grant 2011/03/B/HS1/04559.

\section{Panel of Experts}

(reviewers for the 'The Polish School of Argumentation' issue)

Floris Bex, University of Groningen, Netherlands

Tadeusz Ciecierski, University of Warsaw, Poland

Jan Albert van Laar, University of Groningen, Netherlands

Marcin Lewiński, Universidade Nova de Lisboa, Portugal

Jim Mackenzie, University of Sydney, Australia

Dima Mohammed, Universidade Nova de Lisboa, Portugal

Steven Patterson, Marygrove College, Detroit, US

Andrea Rocci, Università della Svizzera italiana, Switzerland

Marina Sbisà, University of Trieste, Italy

Krzysztof Szymanek, University of Silesia, Katowice, Poland

Mariusz Urbański, Adam Mickiewicz University, Poznań, Poland

Jacky Visser, University of Amsterdam, Netherlands

Konrad Zdanowski, Cardinal Stefan Wyszyński University, Warsaw, Poland

Open Access This article is distributed under the terms of the Creative Commons Attribution License which permits any use, distribution, and reproduction in any medium, provided the original author(s) and the source are credited. 


\section{References}

Bogołębska, B. 2006. Konteksty stylistyczne i retoryczne [Stylistic and rhetorical contexts]. Łódź.

Budzynska, K., Araszkiewicz, M., Bogołębska, B., Cap, P., Ciecierski, T., Debowska-Kozlowska, K., Dunin-Kȩplicz, B., Dziubiński, M., Federowicz, M., Gomolińska, A., Grabowski, A., Hołówka, T., Jochemczyk, Ł., Kacprzak, M., Kawalec, P., Kielar, M., Kisielewicz, A., Koszowy, M., Kublikowski, R., Kulicki, P., Kuzio, A., Lewiński, P., Lichański, J.Z., Malinowski, J., Marciszewski, W., Nieznański, E., Pietrzak, J., Pogonowski, J., Puczyłowski, T.A., Rytel, J., Sawicka, A., Selinger, M., Skowron, A., Skulska, J., Smolak, M., Sokół, M., Sowińska, A., Stalmaszczyk, P., Stawecki, T., Stepaniuk, J., Strachocka, A., Suchoń, W., Szymanek, K., Tomczyk, J., Trypuz, R., Trzȩsicki, K., Urbański, M., Wasilewska-Kamińska, E., Wieczorek, K.A., Witek, M., WybraniecSkardowska, U., Yaskorska, O., Załęska, M., Zdanowski, K., and T. Żurek. 2014. This issue. The Polish School of Argumentation: A Manifesto. In Argumentation, special issue "The Polish School of Argumentation", ed. K. Budzynska and M. Koszowy, volume 3.

Budzynska, K., van Eemeren, F.H., and M. Koszowy. (eds.). 2014. Special issue on pragmatics and dialectics of argument; Studies in Logic, Grammar and Rhetoric, volume 36(49).

Dignum, F., B. Dunin-Kȩplicz, and R. Verbrugge. 2001. Creating collective intention through dialogue. Logic Journal of the IGPL 9: 145-158.

Dunin-Kȩplicz, B., and R. Verbrugge. 2010. Teamwork in multi-agent systems: A formal approach. New York: Wiley and Sons.

Gizbert-Studnicki, T. 2012. Consensus and objectivity of legal argumentation. In Proceedings of the conference Argumentation 2012 (International conference on alternative methods of argumentation in law), ed. M. Araszkiewicz, M. Myska, T. Smejkalova, J. Savelka, and M. Skop, 1-14.

Grabowski, A. 2003. Sonderfallthese: Its critique and interpretation. Rechtstheorie 34: 371-392.

Hołówka, T. 2007. Kultura logiczna w przykładach [Logical education in examples]. PWN.

Koszowy, M. (ed.). 2009. Special issue on informal logic and argumentation theory; Studies in Logic, Grammar and Rhetoric, volume 16(29).

Koszowy, M. 2011. Pragmatic logic: The study of argumentation in the Lvov-Warsaw School. In Proceedings of ISSA'10.

Koszowy, M. (ed.). 2011. Special issue on argument and computation; Studies in Logic, Grammar and Rhetoric, volume 23(36).

Koszowy, M., and M. Araszkiewicz. 2014. This issue. Lvov-Warsaw School as a source of inspiration for argumentation theory. In Argumentation, special issue "The Polish School of Argumentation", ed. K. Budzynska and M. Koszowy, volume 3.

Lichański, J. 2003. Retoryka w Polsce. Studia o historii, nauczaniu i teorii w czasach I Rzeczypospolitej [Rhetoric in Poland. Studies on history, teaching and theory in times of the First Republic of Poland]. Warszawa: Wyd. DiG.

Smolak, M. 2003. Uzasadnianie sadowe jako argumentacja z moralności politycznej. O legitymizacji władzy ş̧dziowskiej [Judicial justification as a moral-political argumentation]. Kraków.

Szymanek, K., Wieczorek, K.A., and A. Wójcik. 2003. Sztuka argumentacji [The art of argumentation]. PWN.

Tokarz, M. 2006. Argumentacja, perswazja, manipulacja [Argumentation, persuasion, manipulation]. Gdańsk: Gdańskie Wydawnictwo Psychologiczne.

van Eemeren, F.H., Garssen, B., Verheij, B., Krabbe, E.C.W., Snoeck Henkemans, A.F., and J.H.M. Wagemans. 2015. Handbook of argumentation theory. Springer. In print.

Załęska, M. 2012. Rhetoric and politics: Central/Eastern European perspectives. Cambridge: Cambridge Scholars Publishing. 